\title{
Authority, Continuity, and Change in Islamic Law
}

\author{
Wael B. Hallaq \\ Cambridge: Cambridge University Press, 2001. 269 pages.
}

This book traces the development of Islamic law from its earliest period to the full formative period, when the major madhahib were established, to show that institutionalizing Islamic law always involved a reasoned defense and calculative move. Hallaq asserts that such processes were not an innovation; rather, they were embedded in the structure of the original legal traditions that allowed for continual social change and the maintenance of order and stability in Islam's social system. Throughout the ages, the Shari 'ah has been subjected to a dialectical milieu and change as dictated by varying social conditions. This further stimulated change to maintain the established order's very essence, which was based on the logic of reasoning and calculation.

The juristic structure of authority did not remain very rigid and conservative as it seemed, except for a few cases. Rather, at a certain level, 
hermeneutics, insightfulness, and self-perception were the objective realities or normative standards when addressing the formulation of law and change and development as such. Under varying sociopolitical and socioeconomic conditions, the schools' founders were challenged to resolve a crisis or respond to an ambiguity. In the process, many other schools, as well as their accompanying methodologies and notions, developed. So, contrary to the popular belief about the supremacy of the Hanafi, Maliki, Shafi ' $i$, and Hanbali schools, as well as the conservative nature of Islamic law, there emerged many other schools with specific hermeneutic tools.

In the first chapter, "Juristic Typologies: A Framework for Enquiry," Hallaq argues that there existed a wide variety of juristic typologies (communities of legal specialists by various formal categories in the context of historical circumstances and similarities within a particular theme) along the lines of specific and original schools, and later deviations. These typologies were developed upon the hierarchical nature of laws, the relationship of one type to another, historical context, and specific social circumstances. Ibn Rushd classified the Maliki school into three categories based on how and to what extent scholars were literalists or used reasoned judgment and a syllogistic apparatus. Abu Amr 'Uthman ibn al-Salah classified the Shafi'i school into six types under two categories, and Shaykh al-Islam Ahmed Ibn Kamal Pashazadeh classified the Hanafi school into seven ranks.

In the second chapter, "Early Ijtihad and the Later Construction of Authority," the author distinguishes between the earlier mujtahidun (main founders) and the later development. The later mujtahid was formed as a continuity when earlier ones had a memory loss or lag, and were based upon historical accounts connected to a chronological rupture and a breakdown in harmony. Hallaq argues that a rupture emanated from systematically developed strategic moves rather than accidental events. This was done to increase the later schools' prestige and supremacy by separating them from the earlier ones, often without exercising any ijtihad (reasoning), and basing them upon personal opinions. To exemplify this point, the author states that every school contained degrees of deviation. The Hanafis and the Shafi 'is deviated the most from the original thinkers, while Malikis remained in the middle and the Hanbalis deviated the least.

The third chapter, "The Rise and Augmentation of School Authority," argues that the "founders" were not truly absolute mujtahidun and did not always exercise ijtihad across the board. Their authority was largely a later creation, partly drawn from their attributions to the prime movers 
and partly to later denial of the earliest jurists' significant contributions to the formation of landmark figures and doctrines. This particular trend was significantly associated with existing ideological biases, namely, often the status quo or recognition that came into being because of individuals' actual contributions and personal charisma, as well as historical forces in conjunction with the period's deciding power structure. For example, the Shafi 'i scholar Muzani was a far more skilled and creative jurist than Ibn Hanbal but did not emerge as a founder, despite the development of a monumental treatise very distinct from the Shafi' $i$ school. Harmala, a student of Shafi'is, was subjected to similar adjudication.

The fourth chapter, "Taqlid: Authority, Hermeneutics, and Function," analyzes taqlid (imitation, emulation, or acceptance of the original doctrine or authority). According to the author, taqlid initially connoted assuming the whole or a part and parcel of the Companions' legal teachings, as well as those of the Followers who had attained a high level of training and understanding during the Companions' lifetime, without involving the acceptance of ijtihadi ruling. As time progressed, its meaning changed to include accepting opinions from individuals (mujtahidun) capable of using independent reasoning. In most cases, however, the procedural activity related to taqlid remained between the two opposites. In addition, taqlid always involved juristic function, not just scholarly legal writing (musannif). Interestingly, some individuals became famous by simply reproducing their predecessors' doctrine, and arrived within the domain of a madhhab (founding authority) contingent upon the local political and religious climates' conducive nature. This particular process depended upon addressing specific cases and sometimes upon their contexts, or both.

In the fifth chapter, "Operative Terminology and the Dynamics of Legal Doctrine," Hallaq states that taqlid (legal authority) was simply an external expression of internal juridical dynamics. At the macro-level, juridical activity remained an uncontested body of the total institutional school, whereas at the micro-level, plurality of opinion within a given school was almost a craft and drama of the time and hermeneutic philosophy. The Hanafi and Maliki schools had divisions, and before his death al-Shafi 'i had developed an "old" and a "new" doctrine. The Hanbalis followed a similar trend. Such doctrinal variety produced an extensive technical vocabulary to distinguish between the types of legal opinion. The opinions developed through takhriz (resolving specific problems by following relevant ahadith as documented by the original narrators) was called wajuh 
by Shafi 'is and Hanbalis, riwayat by Malikis, and aqwal by Malikis. This technical variation, which started early on due to the absence of a central political authority, influenced later fiqh formulation.

Hallaq strongly asserts in the sixth chapter, "The Jurisconsult, the Author-Jurist, and Legal Change," that despite categorical denial by some contemporary Muslim scholars, change occurred within the Islamic legal system even after the formative period. These changes were not unwarranted, for they took place within the congruency of tools that were fundamental and a structural feature of Islamic law. Thus, this part of the book addresses the basic notion of fatwa (ruling under the dictates of circumstances). The author points out that this act and its process became an essential component of Islamic societies, varying across spatial geopolitical zones, dictated by the passage of time or changing social conditions. The four professions involved here are the qadi (judge), the mufti (jurisconsult), the musannif (author-jurist), and the professor. Most of the time they functioned interdependently.

In summary, the author has proved himself to be a very high level scholar through his unique writing style and his central thesis that the foundation of Islamic legal scholarship was far more flexible than conceptualized by some contemporary Islamicists. And, moreover, that such act of scholarship and the associated process often involved a continuous use of reasoning, calculation, and functional logic in a very coherent fashion, a methodological approach rooted in classical Islamic tradition. Hallaq successfully probes the issue under investigation by moving his initial thesis from conjecturing to establishing a theory to its fullest extent, accompanied by factually substantive evidence and scientific logic. In the process of exploration and analysis to reach the final synthesis, all six chapters and the concluding section remained in absolute congruency and full harmony. However, the book falls short of its ultimate supremacy in terms of appealing to a much larger and non-scholarly audience. A somewhat simplified approach in terms of language, structure, and philosophy would be helpful, and a little less complicated approach would allow the general reader to access this book and have a greater understanding of how fiqh developed. 